Case Report

\title{
Effect Stick of Miswak on Periodontal Reccesion to Jama'ah Tabligh Kerung Kerung Kota Makassar, Indonesia
}

\author{
Muhammad Saleh $^{1}$, Nurhaeni ${ }^{1}$, Oke Sainuddin ${ }^{1}$, Syamsuddin Abubakar $^{1}$, Johny Angki ${ }^{1}$, \\ Yayah Sopianah ${ }^{2}$, Hadiyat Miko ${ }^{2, *}$ \\ ${ }^{1}$ Departement of Dental Nursing, Polytechnic of Health Makassar, Makassar, South Sulawesi, Indonesia \\ ${ }^{2}$ Dental Nursing, Polytechnic of Health Tasikmalaya, Tasikmalaya, West Java, Indonesia
}

Email address:

drgmiko@yahoo.com (H. Miko)

${ }^{*}$ Corresponding author

\section{To cite this article:}

Muhammad Saleh, Nurhaeni, Oke Sainuddin, Syamsuddin Abubakar, Johny Angki, Yayah Sopianah, Hadiyat Miko. Effect Stick of Miswak on Periodontal Reccesion to Jama'ah Tabligh Kerung Kerung Kota Makassar, Indonesia. International Journal of Dental Medicine. Vol. 3, No. 1, 2017, pp. 1-3. doi: 10.11648/j.ijdm.20170301.11

Received: August 27, 2016; Accepted: September 23, 2016; Published: February 9, 2017

\begin{abstract}
Descriptive studies have explored the relationship between toothbrushing with miswak stick and development of periodontal/gingival recession, but relevant periodontal/gingival recession data for the multidirectional power Miswak are lacking. The aim of this study is to descriptive the effect of brushing with either a multidirectional Miswak or manual toothbrush defect or periodontal/gingival recession on anterior/labial surface of gum at miswak user of 30-60 years old.
\end{abstract}

Keywords: Miswak Stick, Defect, Periodontal Recession, Jama'ahTabligh

\section{Background of the Problem}

Miswak or in Latin called Salvadora Persica, originally was used as a tool for cleaning teeth and mouth long before Islam developed, the Arabs also use miswak as a tool for cleaning teeth and mouth. Historically, miswak is one tool used to clean the teeth and mouth which is still in use, especially among Muslims (E, Noumi., Et al, 2010). Miswak is a culture of the ancient people used to clean teeth and a healthy mouth.

Miswak common among the not so well known in modern times. Dentists have always advocated clean my teeth with a toothbrush with a variety of forms that have been through quality test, we know the shape of a toothbrush the most effective way to clean up the leftovers, but in the modern era through various studies also found the contents of chemical from miswak turns very beneficial for oral health (Khoory, T, 1983).

The chemicals contained in miswak turned out to have much effect on oral health, its contents can reduce dental caries, improve the health of the gums and periodontal status, whiten teeth, remove tartar, and has an antimicrobial effect

\section{(Masood, 2010).}

Another study conducted by Eid and Salim, (1994) informs that there is a correlation between the use Miswak with events gum recession (gingival recession). Further stated that in addition to gum recession due to natural factors such as age, also in many cases due to trauma or brushing teeth cleaning and brushing improper manner.

The use of miswak in Indonesia itself is generally a bit more attention hygienists. Research conducted Samiaji, (2014) in Jamaat Tabligh Tasikmalaya concluded that the use Miswak for teeth cleaning is not better than the modern toothbrush, this is due to the anatomical shape Miswak straight from the base of the handle until the fibers Miswak. Users miswak also general save Miswak in your pocket or pants so that are less clean and can support bacterial growth

Research conducted Kartilah, T., et al (2016) also concluded that most users Miswak in Pesantren al-Kautsar District Kuningan did not understand the technique of using miswak with true so that oral hygiene is not optimal Miswak users. Less precise techniques tend to result in disruption of periodontal tissue.

Recognizing that periodontal disease is a disease that affects 
many people in various countries of the World Health Organization (WHO) took the initiative to organize groups of researchers from many WHO member states to conduct studies in order to provide advice in terms epidemiology, etiology, and prevention of periodontal disease. Measurement of periodontal tissue covering Periodontal Index (PI), Periodontal Disease Index (PDI), Gingival Index (GI), Gingival Bleeding Index (GBI), and the Community Periodontal Index Treatments For Needs (CPITN). (WHO, 2003).

Based on the description of the above problems, the authors are interested in doing research on Effect Stick of Miswak on Periodontal Reccesion to Jama'ah Tabligh Kerung Kerung Kota Makassar, Indonesia.

Research Purpose:

To determine Periodontal tissues after brushing teeth using miswak.

\section{Material and Methods}

This type of research is a simple descriptive approach to observation and data gathering simultaneously at the same time period (Notoatmodjo 2002).

The population in this study is Jama'ah Tabligh Kerung Kerung of Makassar which amounted to 292 people. Samples are 20 people using accidental sampling technique is sampling potluck, with the inclusion criteria ie Jama'a who use Miswak, using Miswak of 6 months to 1 year, Tablighis using Miswak more than 1 year, willing the subject of research.

The equipment used in the study are as follows: diagnostic set (sonde, excavators, tweezers, mirror mouth), Nier beiken, WHO periodontal probe, rinse cups, filling CPITN sheets, stationery, bucket.

Materials used in this study are cotton, cotton roll, alcohol, masks, Handschoen.

The research was conducted in 1 (one) day in the 2 nd week of April 2015. The study was conducted one inspection by brushing teeth using Miswak to know the technique of using Miswak then examined the periodontal tissues.

Analysis of the data in this study is the use of data processing frequency distribution to determine the effect of toothbrushing using Miswak against periodontal tissue in Jama'ah Tabligh Kerung Kerung Makassar.

\section{Result and Discussion}

The-study was performed on 20 Jama'ah Tabligh Kerung Kerung Kota Makassar on 18 April 2015. The data collection technique was Accidental Sampling. The table 1 below showed that there were 16 male members of Jama'ah Tabligh Kerung Kerung Makassar

Table 1. Frequency Distribution of Research Samples by Sex.

\begin{tabular}{llll}
\hline No & Sex & Frequencies & Percentages (\%) \\
\hline 1 & Male & 16 & $80 \%$ \\
2 & Female & 4 & $20 \%$ \\
& Mount & 20 & $100 \%$ \\
\hline
\end{tabular}

Male $(80 \%)$, higher than female members of Jama'ah Tabligh, of which there were only $4(20 \%)$. Jama'ah was grouped by age as follows:
Table 2. Frequency Distribution of Research Samples by Age.

\begin{tabular}{llll}
\hline No & Age group (Year) & Frequencies & Percentages (\%) \\
\hline 1 & $30-35$ & 7 & $35 \%$ \\
2 & $36-40$ & 6 & $30 \%$ \\
3 & $41-45$ & 3 & $15 \%$ \\
4 & $45-50$ & 1 & $5 \%$ \\
5 & $50-55$ & 3 & $25 \%$ \\
& Mount & 20 & $110 \%$ \\
\hline
\end{tabular}

Age group of sex in 30-35 years

Table 3. Frequency Distribution of Research Samples byExamination of Condition of Periodontal Tissues (CPITN).

\begin{tabular}{lllll}
\hline NO & Score & Periodontal Tissue Condition & Total & Percentage \\
\hline 1 & 0 & Healthy Periodontal condition & 0 & $0 \%$ \\
2 & 1 & Bleeding & 0 & $0 \%$ \\
3 & 2 & Tartar & 7 & $35 \%$ \\
4 & 3 & Shallow pocket $(3,5-5,5 \mathrm{~mm})$ & 9 & $45 \%$ \\
5 & 4 & Deep pocket (over 5,5 mm) & 4 & $20 \%$ \\
& Total & 20 & $100 \%$ \\
\hline
\end{tabular}

Table 4. Frequency Distribution of Research by length.

\begin{tabular}{lll}
\hline \multirow{2}{*}{ Score } & Based on Length & \\
\cline { 2 - 3 } & 6 month- 1 year & 1 year \\
\hline 0 & 0 & 0 \\
1 & 0 & 0 \\
2 & 4 & 3 \\
3 & 3 & 6 \\
4 & 1 & 3 \\
\hline
\end{tabular}

Table 3 above shows the result of examination of condition of periodontal tissues was healthy, 0 had bleeding, 7 people had tartar (35\%), 9 people had shallow pocket $(45 \%), 4$ had deep pocket $(20 \%)$.

The table 4 above shows that $40 \%$ had used miswak for 6 month-1 year and $60 \%$ had used it for over 1 year.

The study was performed on 20 Jama'ah Tabligh Kerung Kerung Kota Makasar. The data collection technique was Accidental Sampling. The study was performed in 1 day on 18 April 2015.

According to Tarigan (1995) gum and periodontal tissue diseases often happen patients at productive age, i.e.:

a. Puberty (teenagers) at 14 to 20 years of age. There is hormonal change which can cause inflammation of the gum, so that patients don't brush their teeth, thus their oral hygiene isn't maintained.

b. At 40 to 50 years age. At this age, there is gum recession, so that food remains are difficult to clean.

The condition of one's periodontal tissues can be known and measured by Community Index of Treatment Needs (CPITN) examination. It's an official index used by World Health Organization (WHO) to measure the condition of Periodontal tissues, as well as estimation and required treatments using a special liquid food (Putri, et al., 2010). Table 4 shows frequency distribution of the condition of periodontal tissues of Jama'ah Tabligh kerung kerung Kota Makassar based on the result of Community Periodontal index of Treatment Needs (CPITN) examination. It found no healthy periodontal tissues, no bleeding, 7 people with tartars $(35 \%), 9$ people with shallow pockets $(45 \%), 4$ people with deep pockets $(20 \%)$. In general, 
periodontal tissues had soft pockets.

Table 4 shows frequency distribution by length of miswak usage. It showed that 12 people had used miswak for over a year. People had gum recession is 13: 9 people had shallow pockets and 4 people had deep pockets. It caused tooth abrasion and trauma on oral soft tissue due to incorrect brushing technique and hard texture of miswak fibers.

Based on the result of the study by Eid and Selim, there is correlation between the usage of miswak and gum recession. Further, it states that beside natural factor, such as age, gum recession is often caused by trauma of cleaning or brushing teeth. The main causes were incorrect brushing tool and method, harder texture of miswak fiber, excessive frequency of usage of miswak everyday (5 times a day) and lack of knowledge on how to use miswak correctly and appropriately.

\section{Conclusion}

The research result showed that 12 people use miswak for over 1 year, 13 people had gum/gingival recession. It caused tooth abrasion and trauma on oral soft tissue due to incorrect brushing technique and hard texture of miswak fibers.

The suggestion for the Jama'ah is to pay attention to how to make appropriate and correct miswak fibers. They also should pay attention to the hygiene of usingmiswak, because a lot of people who use miswak don't pay attention to that factor. For example, many members of Jama'ah don't wash themiswak after usage and only store the miswak in their pockets.

\section{References}

[1] Eid, MA, HA Selim., 1994 Retrospective study of the Relationship Between Miswak Chewing Stick and Periodontal Health.
[2] Khoory, T. 1983. The Use of Chewing Sticks in Preventive Oral Hygiene. Journal of Clinical Preventive Dentistry.

[3] Masood, Y., Masood, M., Hassan, M. I. A., Bayaty, F. H. MA., 2010, Biological Effect Of Miswak (salvadora persica), CurrentTopics In Nutraseutical Research, Vol 8, 161-168.

[4] Noumi, E., 2010, Antifungal Properties of Salvadora Persica and Juglans Regia L Extracts Againts Oral Candida Strains, European Journal of Clinical Microbiology and Infectious Diseases, vol 29, 81-88.

[5] Notoatmodjo, S., 2010, Metodologi Penelitian Kesehatan, Rineka Cipta, Jakarta.

[6] Putri, M. H. Herijulianti. E. dan Nurjannah. N., 2012, Ilmu Pencegahan Penyakit Jaringan Keras dan Jaringan Pendukung Gigi. EGC. Jakarta.

[7] Samjaji, 2014, Miswak dan Kesehatan Gigi Study pada Jamaah Tabligh Kota Tasikmalaya. Tesis Sekolah Pascasarjana UIN Syarif Hidayatullah Jakarta. Jakarta.

[8] Tarigan, R, 1995. Kesehatan Gigi dan MulutCetakan Ke Empat, Penerbit Buku.

[9] Kartilah, T., Miko, H., Suwarsono., Trianto, R., 2016. Pengaruh BerMiswak dengan menggunakan Alat Bantu Modifikasi Terhadap Kebersihan Gigi dan Mulut Pada Santri di Pondok Pesantren Al-Kautsar Kabupaten Kuningan Jawa Barat. Journal ARSA (Actual Research Science Academic), vol 1(1), 33-41.

[10] The World Oral Health Report 2003: Continuous improvement of oral health in the 21st century - the approach of the WHO Global Oral Health Programme. Geneva, World Health Organization, 2003. 